\title{
The Performance of Three Different Solar Panels for Solar Electricity Applying Solar Tracking Device under the Malaysian Climate Condition
}

\author{
Azhar Ghazali M. ${ }^{1}$ \& Abdul Malek Abdul Rahman ${ }^{1}$ \\ ${ }^{1}$ School of Housing, Building and Planning, Universiti Sains Malaysia, Pulau Pinang, Malaysia \\ Correspondence: Azhar Ghazali M., School of Housing, Building and Planning, Universiti Sains Malaysia, 11800 \\ Pulau Pinang, Malaysia. Tel: 60-046-572-810. E-mail: azhar.dtyco@gmail.com
}

Received: August 15, 2011 Accepted: August 29, 2011 Online Published: May 29, 2012

doi:10.5539/eer.v2n1p235 URL: http://dx.doi.org/10.5539/eer.v2n1p235

\begin{abstract}
The main objective of this study was to measure and determine the efficiency of poly-crystalline, mono-crystalline and amorphous silicon solar module by applying single-axis time/date solar tracker to the installation of photovoltaic panel (dynamic system) as a strategy to increase the performance of the modules under hot-humid climate of Malaysia. The dynamic system in this experiment was designed to support the three types of PV panels which allowed it to move with single degree of freedom (horizontally) according to the sun's orientation (sunrise to sunset) from east to west. Studies on sun movement in equator countries have been conducted to locate the sun's position on site (azimuth and altitude angle) using the Stereographic Diagram and Tabulate Daily Solar Data. It was found that poly-crystalline solar module have shown better performance ratio and average module efficiency compare to the others tested PV module under Malaysian climate.
\end{abstract}

Keywords: photovoltaic system, building integrated photovoltaic (BiPV), tropical climate, solar tracker

\section{Introduction}

Excessive usages of fossil fuel as main energy source have become the main factor that contributes to the global warming. Carbon dioxide emissions from the combustion of fossil fuel increase the temperature of the atmosphere. As Malaysia move towards a developed country, energy requirement will remain very intensive. At present, almost half the energy consumption in the nation is consumed by the industrial, residential and commercial sector (APEC, 2006). This means Malaysia has a strong need to apply energy efficient strategies in lowering energy consumption in buildings.

Solar energy has been acknowledged as a free and infinite source of energy and provides an alternative energy where there is no pollution of the environment and its use will decreases the rate of depletion of energy reserves (A. M. Sharan, 2008). As one of renewable energy, solar energy represents a massive energy potential greatly exceeding the fossil fuels. Malaysia lies in the tropical region between $1^{\circ} \mathrm{N}$ and $7^{\circ} \mathrm{N}$, and $100^{\circ} \mathrm{E}$ and $119^{\circ} \mathrm{E}$ (Kamaruddin et al, 2002). Its weather condition in Malaysia is very suitable for photovoltaic implementation, this is because the weather condition is almost predictable and the availability of sunlight for more than ten hours daily with almost six hours of direct sunlight with irradiation of between $800 \mathrm{~W} / \mathrm{m}^{2}$ and $1000 \mathrm{~W} / \mathrm{m}^{2}(\mathrm{~N}$. Amin et al, 2009).

According to Deo Prasad and Mark Snow (2005), photovoltaic are solid-state devices that simply make electricity out of sunlight, silently and with little to no maintenance, no pollution and no significant depletion of material resources. According to T. Markvart, (1994), the design of the photovoltaic system relies on the input of measured data close to the site of the installation which is the regular daily and yearly variation due to the apparent motion of the sun, irregular variations are caused by the climate condition (cloud cover), as well as by general composition of the atmosphere. Besides that, different materials and different structures of photovoltaic panels provide different efficiency in term of power conversion.

According to A. J. Carr and T. L. Pryor (2004), photovoltaic technologies have different seasonal patterns of behavior and these differences are due to the variations in spectral response. There is evidence that modules of differing technologies could be more suited to certain specific climates. Mieke (1998) for example, has reported that in this tropical climate, with high ambient temperatures and high humidity during the wet season, the a-Si 
array produces up to $20 \%$ more energy than the p-Si array. Akhmad et al. (1997) have also indicated that a-Si modules may be more suited to tropical climates. N. Amin et al. (2009) found that Amorphous silicon and Copper Indium Diselenide (CIS) solar cell have shown better performance ratio than mono- and multi-crystalline silicon solar cells in Malaysia climate condition.

Commonly in Malaysia, PV panels were installed fix to the building either on the roof this installation considered as static system. These static systems only maximize sun availability at certain time during daytime. A dynamic system use Solar Tracker; a device for orientating Photovoltaic Panel (PV) towards the sun. This is to ensure that the concentration sunlight is directed to the focal point of the PV and this will improve the amount of power produced by the system by enhancing morning and afternoon performances. The use of tracking technology allowing solar modules to follow the course of the sun (and optimize the incident angle of sunlight on their surface) can increase electricity production by around a third, and some claim by as much as $40 \%$ in some region, compared with modules at a fixed angle (Appleyard, 2009).

This research focuses on the three common types of solar panels available in the Malaysian market and to identify the most efficient in term of power conversion using single-axis time/date tracking system by optimizing the sunlight and also to compare the performance between static system and dynamic system. Primarily for the Engineers and Architects, this research will help them identify critical technical factors in maximizing the energy output of different types of PV technologies.

\section{Methodology}

In Malaysia, the sun is always directly overhead and its solar intensity do not varies by season, and for this matter Single-axis time/date solar tracker is used based on method suggested by Abdallah S. and Badran O. O. (2008) and Francisco Duarte et al. (2010). Therefore, the movements of the PV panels during daytime are perpendicularly toward the sun and followed it from east to west.

This type of method was selected due to following reasons:

i. Cost: The cost of this method is cheaper compare to the other method due to simpler mechanism.

ii. Simple mechanism: This system consider a simple system compared to the other two active system because there's no need the use of sensor which is costly and the control system are based on step motor and gear speed.

iii. Low energy consumption: The power consumption by the motor and electric system was estimated to be $3 \%$ of the collected energy. This also increase the power output of overall PV system.

iv. Availability of cloud: as sensors are not advisable to be used in Malaysian climatic conditions because of the heavy cloud cover. Sudden change in sky condition might interrupt the signal to the sensor.

v. Efficiency: although this method are less efficient compare to the other method, but the cost and the simple mechanism outdone the other method.

According to Agee et al. (2007) in their studies on the market trends and field application of solar tracking technologies founded that the single-axis tracking system's performance was similar to two-axis type, while its cost was equal to that single-axis tracking system. Meanwhile, the used of photo-sensor may cause unstable states under overcast and partly cloudy weather conditions when the photo-sensor do not see the sun (Abdalah \& Nijmeh, 2002).

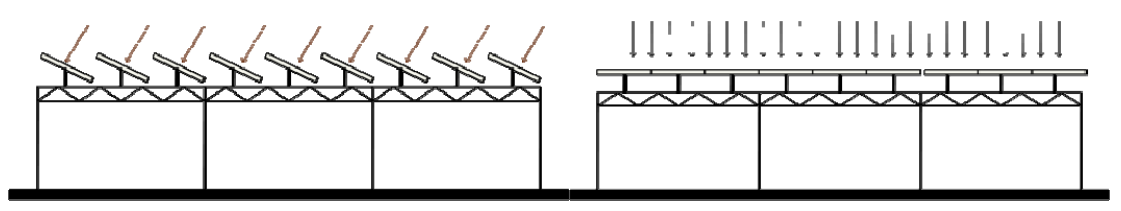

(a)

(c)

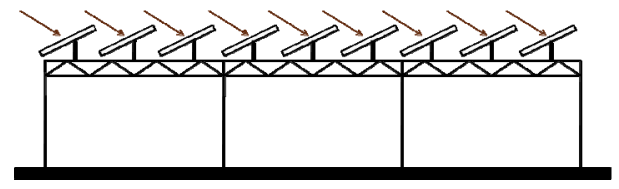

(b)

Figure 1. (a) Panels oriented towards morning sun. (b) Panels oriented directly under mid afternoon sun. (c) Panels oriented towards afternoon sun 
The system in this experiment is design to support the three types of PV panels which allowed it to move with single degree of freedom (horizontally) according to the sun's orientation (sunrise to sunset) from east to west. Studies on sun's movement in equator countries have been conducted to indicate the sun's position on site (azimuth and altitude angle) using the Stereographic diagram. Figure 1 show, the basic diagram of the panel's movement according to sun's position in morning, noon and evening. This movement allowed the PV panels to set perpendicularly toward the sun insolation (incoming solar radiation) so that solar rays can be optimized from morning until evening.

Table 1. Orientation (East, E and West, W) of the Panels at each 30 minutes

\begin{tabular}{|c|c|c|c|}
\hline Time (daylight saving) & Local Time & Altitude of sun angle $\left({ }^{\circ}\right)$ & \multirow{2}{*}{ Angle of the panels $\left(^{\circ}\right)$} \\
\hline \multicolumn{3}{|c|}{ From Tabulated Daily Solar } & \\
\hline 09:00 & 08:00 & 25.9 & $60 \mathrm{E}$ \\
\hline 09:30 & 08:30 & 33.4 & $60 \mathrm{E}$ \\
\hline 10:00 & 09:00 & 40.8 & $60 \mathrm{E}$ \\
\hline $10: 30$ & 09:30 & 48.3 & $65 \mathrm{E}$ \\
\hline 11:00 & 10:00 & 55.7 & $70 \mathrm{E}$ \\
\hline $11: 30$ & $10: 30$ & 63.1 & $75 \mathrm{E}$ \\
\hline $12: 00$ & 11:00 & 70.6 & $80 \mathrm{E}$ \\
\hline $12: 30$ & $11: 30$ & 78 & $85 \mathrm{E}$ \\
\hline 13:00 & $12: 00$ & 85.2 & 90 \\
\hline $13: 30$ & $12: 30$ & 86.5 & $85 \mathrm{~W}$ \\
\hline $14: 00$ & 13:00 & 79.4 & $80 \mathrm{~W}$ \\
\hline $14: 30$ & $13: 30$ & 72 & $75 \mathrm{~W}$ \\
\hline $15: 00$ & 14:00 & 64.6 & $70 \mathrm{~W}$ \\
\hline $15: 30$ & $14: 30$ & 57.1 & $65 \mathrm{~W}$ \\
\hline $16: 00$ & $15: 00$ & 46.7 & $60 \mathrm{~W}$ \\
\hline
\end{tabular}

With the clock running, the electrical motors control the drives of the panel's support structure to the desired position. The electrical motor run at every 30 minutes, in order to orientate the panel support structure to the position. The runtime of this process was done between 09:00 and 16:00 at local time (daylight saving) or in local time between 8:00 and 15:00. The standard position of the panel was programmed in the motor control mode, starting from 09:00 (local daylight saving) at $60^{\circ}$ East. At 23:00 (daylight saving) of each day it commanded the panel's structure to the standard position and starting at 09:00 (local daylight saving) on the next day, the microcontroller sends the command every 30 minutes to the motor, to move them in the desired position. With this control mechanism, the PV panels will be orientated toward the sun to maximize the insolation on the PV panels at every 30 minutes between 09:00 and 16:00 every day. Table 1 shows the orientation (East, E and West, W) of the Panels at each 30 minutes. The three types of PV installed are exposed to condition which are exactly identical, which is during the same period, with identical stand and near to each other, so all the three type of PV panels received the same solar radiation, so readings can be compared to verify the efficiency of the panels under the northern region climatic conditions. All the reading or parameters produced by the installed photovoltaic panels was stored in data logger in the control room every 15 minutes. In this installation, the right three rows are installed with amorphous solar panels, the middle three rows are the mono-crystalline and the left three rows are installed with polycrystalline panels with its own specification.

There are 4 parameters were collected from each of the photovoltaic module for each stage of this experiment, that is Current (A), Voltage $(\mathrm{V})$, Module temperature $\left({ }^{\circ} \mathrm{C}\right)$ and Power $(\mathrm{W})$. While parameters to determine the environmental condition that influences the performance of photovoltaic module is Solar Radiation $\left(\mathrm{W} / \mathrm{m}^{2}\right)$ and Ambient Temperature $\left({ }^{\circ} \mathrm{C}\right)$. Power output efficiency, average module efficiency and performance ratio have been used to measure the performance of each type of the panels installed by using the equation below which was adopted from N. Amin, et al. (2009), Deo Prasad and Mark Snow (2005), and A. J. Carr, T. L. Pryor (2003) (respectively): 


$$
\eta_{P}=\left(P_{\text {mea }} / P_{\max }\right) \times 100 \%
$$

$\eta_{P} \quad$ Power output efficiency (\%)

$P_{\text {mea }} \quad$ Average power output (W) measured on site in the given period

$P_{\max } \quad$ Maximum power output (W) of panel

$$
\eta_{\text {eve }}=\frac{P_{\text {eve } m e a}}{P V_{A} \cdot H} \times 100 \%
$$

$\eta_{\text {eve }} \quad$ Average module efficiency (\%)

$P_{\text {eve-mea }} \quad$ Average power output (W) measured on site in the given period

$H \quad$ Average incident radiation $\left(\mathrm{W} / \mathrm{m}^{2}\right)$ on site in the given period

$P V_{A} \quad$ Surface area $\left(\mathrm{m}^{2}\right)$

$$
P R=\frac{P_{\text {eve }} \text { mea }}{P_{\max }} / \frac{H}{G_{S T C}}
$$

$P R \quad$ Performance Ratio

$P_{\text {eve-mea }} \quad$ Average power output (W) measured on site in the given period.

$P_{\max } \quad$ Maximum power output (W) of panel.

$H \quad$ Average incident radiation $\left(\mathrm{W} / \mathrm{m}^{2}\right)$ on site in the given period.

$G_{S T C} \quad$ Irradiance at STC $\left(\mathrm{W} / \mathrm{m}^{2}\right)=1000 \mathrm{~W} / \mathrm{m}^{2}$

\section{Result and Discussion}

The performance of each solar module cannot be obtained by observing the power output of the module because each type of photovoltaic module has different efficiency, Therefore, the power output efficiency have to be normalize to the ratings of each module should be use in order to compare them. The output efficiency will show how much power is actually generate at a specific time over the installed capacity of the module (N. Amin et al., 2009).

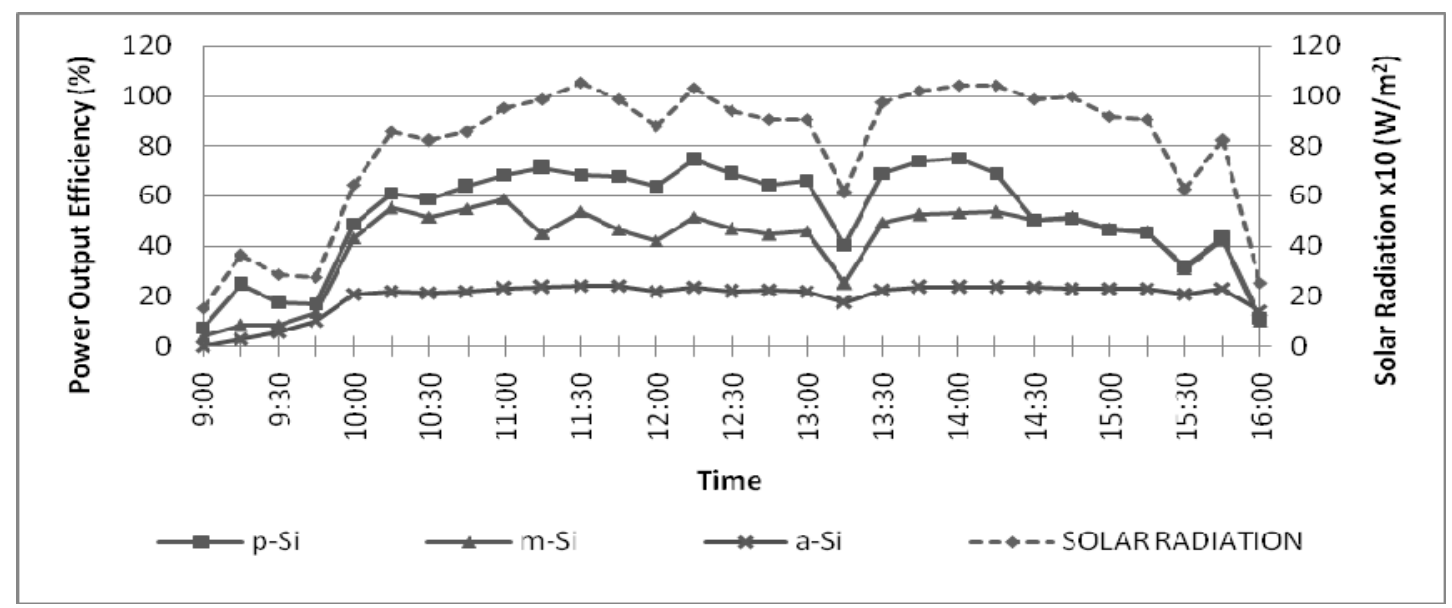

Figure 2. Power output efficiency and solar radiation - Time for day 1

Figure 2 shows the normalized power output efficiency for day 1 with an average solar radiation $796.16 \mathrm{~W} / \mathrm{m}^{2}$. With this amount of average solar radiation per day, it was consider a sunny day when most of the time the solar radiation are above $600 \mathrm{~W} / \mathrm{m}^{2}$. It can be seen that, poly-crystalline panel produced more power than mono-crystalline and amorphous panels in high insolation. Poly-crystalline and mono-crystalline power outputs are inclining almost at the same rate as solar radiation, while amorphous power output is at low level almost at the 
same level from 10:30 to 15:15. The average performances of poly-crystalline, mono-crystalline and amorphous on day 1 are $52.35 \%, 40.90 \%$ and $19.65 \%$ (respectively).

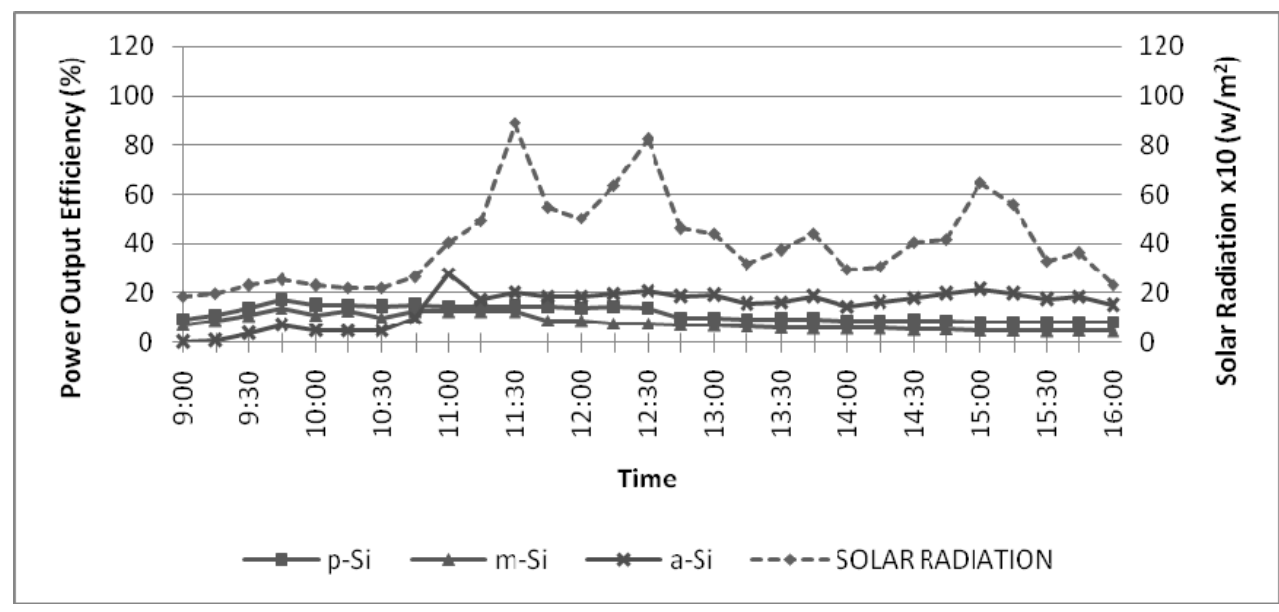

Figure 3. Power output efficiency and solar radiation - Time for day 2

Meanwhile in Figure 3, average solar radiation in day 2 was below $600 \mathrm{~W} / \mathrm{m}^{2}$ and it was considered a cloudy day. By looking at the solar radiation trend line, the amount of solar radiation was fluctuated and slowly decreased between 11:30 to15:00. The result of power output efficiency in day 2 shows that amorphous silicon cell created more energy than poly-crystalline and mono-crystalline cell with average power output efficiency $14.63 \%$ for amorphous, $11.58 \%$ for poly-crystalline and only $8.09 \%$ for mono-crystalline panel.

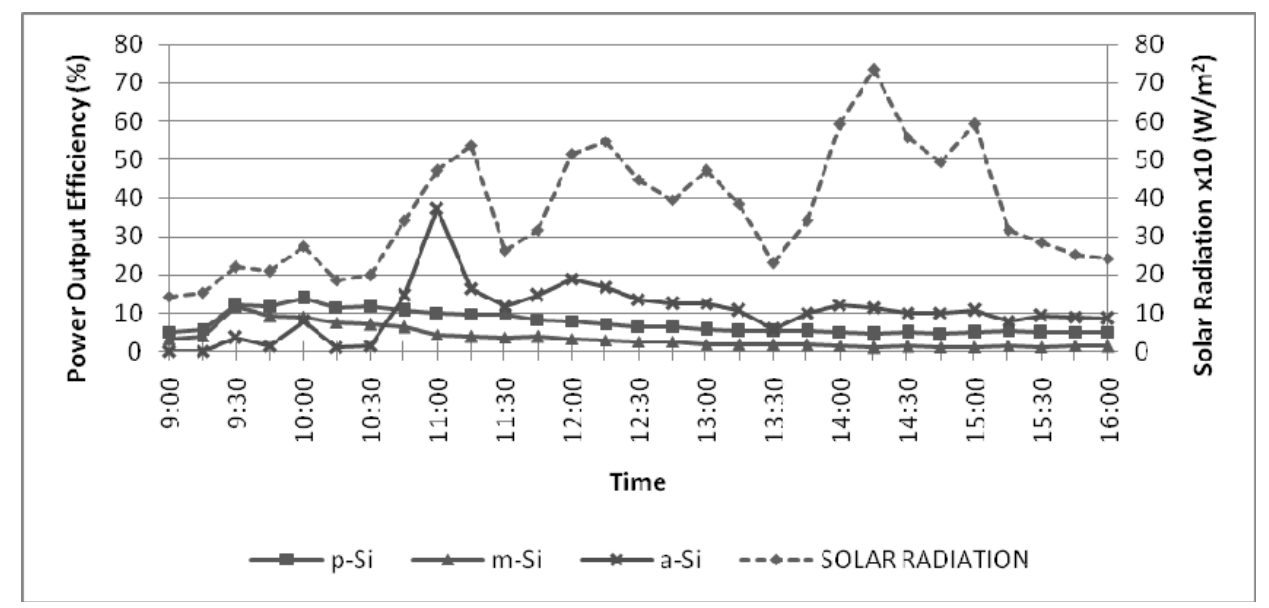

Figure 4. Power output efficiency and solar radiation - Time for day 3

The same trends also occur in day 3 regarding the power output efficiency for each type of photovoltaic panels. Figure 4 shows, that amorphous panel (10.28\% in average) produced higher power output compared to poly-crystalline $(7.33 \%)$ and mono-crystalline panels $(3.53 \%)$. The average of solar radiation is also below $600 \mathrm{~W} / \mathrm{m}^{2}$, which is considered a cloudy day. From the graph it can be seen that, in morning hour before 10:45, the power output of poly-crystalline was much higher than mono-crystalline and amorphous panel, but after 10:45 the trend was reversed. Amorphous power output increased gradually while poly-crystalline and mono-crystalline panels decreased slowly toward that evening. 


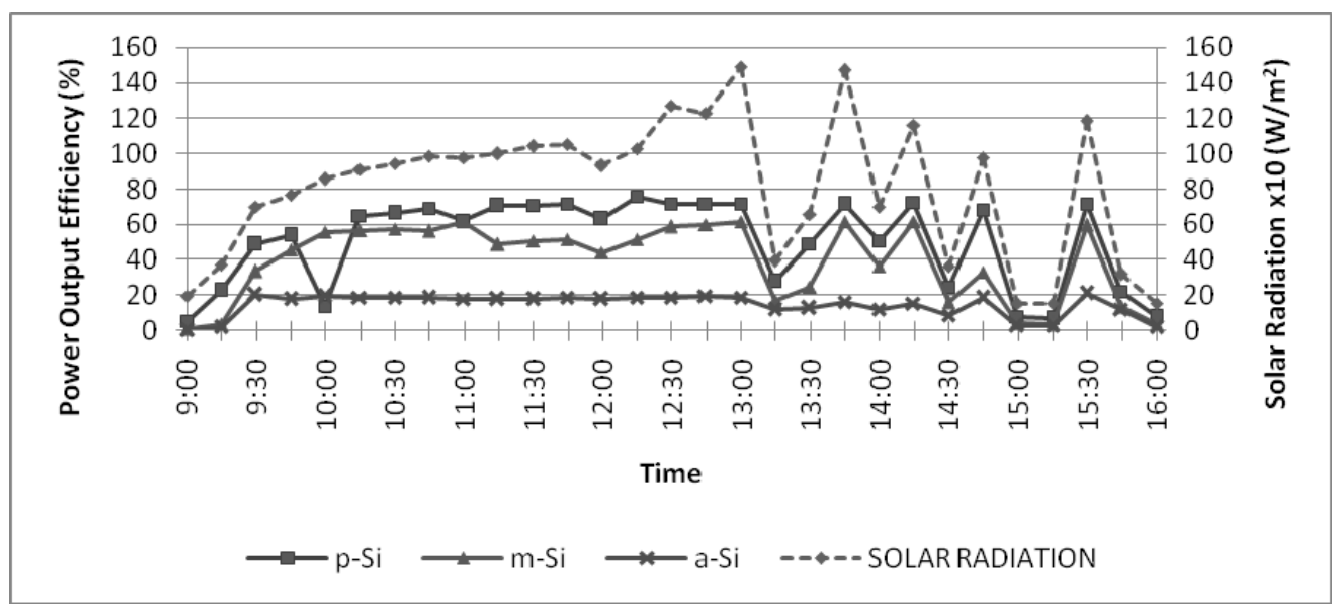

Figure 5. Power output efficiency and solar radiation - Time for day 4

By observing the graph in Figure 5, it can be seen that the solar radiation in day 4 were very high most of the time with average $807.49 \mathrm{~W} / \mathrm{m}^{2}$ and it was increase gradually from 9:00 until 13:00, but after 13:00 the solar radiation level was fluctuated until 16:00 due to the present of scattered cloud cover. The trend line of solar radiation also affected the power output efficiency for poly-crystalline and mono-crystalline. During day 4, poly-crystalline panel produced higher power output with average efficiency of power output $50.08 \%$, while mono-crystalline and amorphous (39.02\% and $14.28 \%$ of average power output efficiency, respectively).

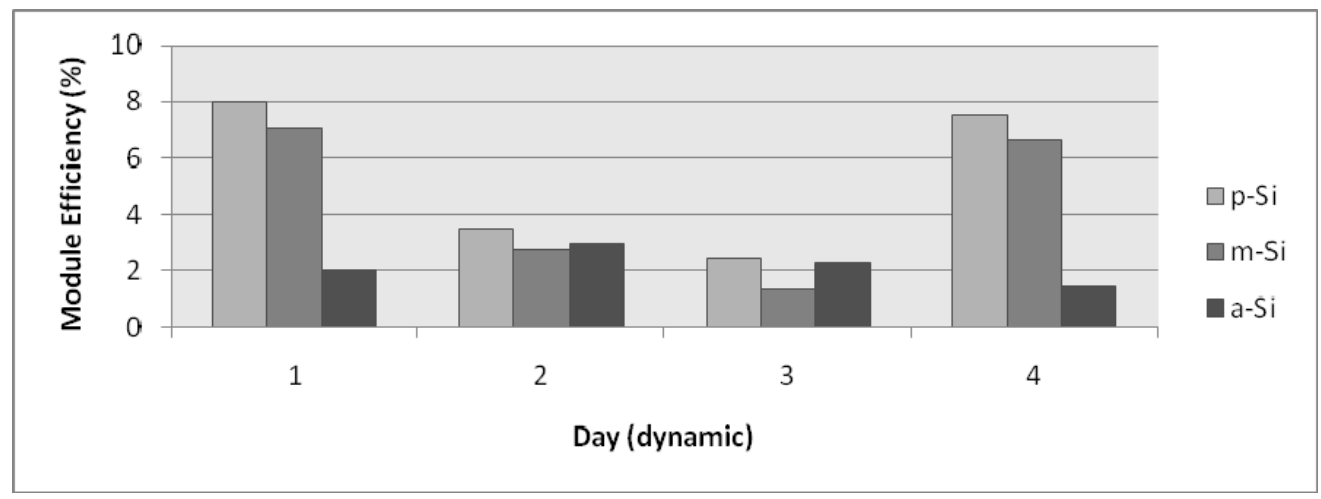

Figure 6. Average module efficiency on site - Day

Table 2. Summary of average power output and average module efficiency data for each type of photovoltaic panels using single-axis time/date solar tracker in 4 days period

\begin{tabular}{|c|c|c|c|c|c|c|c|}
\hline \multirow[t]{2}{*}{ Day } & \multirow{2}{*}{$\begin{array}{c}\text { Average Solar } \\
\text { Radiation } \\
\left(\mathrm{W} / \mathrm{m}^{2}\right)\end{array}$} & $\begin{array}{c}\text { Average } \\
\text { Power (W) }\end{array}$ & $\begin{array}{c}\text { Average } \\
\text { Module } \\
\text { Efficiency }(\%)\end{array}$ & $\begin{array}{c}\text { Average } \\
\text { Power }(\mathrm{W})\end{array}$ & $\begin{array}{c}\text { Average } \\
\text { Module } \\
\text { Efficiency }(\%)\end{array}$ & $\begin{array}{c}\text { Average } \\
\text { Power (W) }\end{array}$ & $\begin{array}{c}\text { Average } \\
\text { Module } \\
\text { Efficiency }(\%)\end{array}$ \\
\hline & & $\mathrm{p}-\mathrm{Si}$ & $\mathrm{p}-\mathrm{Si}$ & $\mathrm{m}-\mathrm{Si}$ & $\mathrm{m}-\mathrm{Si}$ & $\mathrm{a}-\mathrm{Si}$ & $\mathrm{a}-\mathrm{Si}$ \\
\hline 1 & 796.16 & 83.76 & 7.97 & 73.63 & 7.06 & 45.20 & 2.00 \\
\hline 2 & 402.24 & 18.53 & 3.49 & 14.56 & 2.76 & 33.66 & 2.95 \\
\hline 3 & 369.00 & 11.73 & 2.41 & 6.35 & 1.31 & 23.64 & 2.26 \\
\hline 4 & 807.49 & 80.12 & 7.52 & 70.23 & 6.64 & 32.84 & 1.43 \\
\hline Mod & $\begin{array}{l}\text { le Efficiency by } \\
\text { Ianufacture }\end{array}$ & & 12.11 & & 13.70 & & 8.10 \\
\hline
\end{tabular}


Efficiency in photovoltaic solar panels is measured by the ability of a panel to convert sunlight into usable energy for human consumption. Knowing the efficiency of a panel is important in order to choose the correct panels for photovoltaic system. The panel efficiency determines the power output of a panel per unit of area (Deo Prasad \& Mark Snow, 2005). Figure 6 shows the bar graph for daily module efficiency for each type of solar panels by using single axis time/date solar tracker in 4 days period. It can be seen that, the daily module efficiency for poly-crystalline module is the highest compare to mono-crystalline and amorphous solar module in 4 days period with efficiency $7.97 \%$ (day 1), 3.49\% (day 2), 2.41\% (day 3) and $7.52 \%$ (day 4). However there are differences in module efficiency between mono-crystalline and amorphous solar module. As shows in graph, mono-crystalline module efficiency in day $1(7.06 \%)$ and day $4(6.64 \%)$ shows a significant higher efficiency compared to amorphous, which is $2.00 \%$ and $1.43 \%$, respectively. While in day 2 and day 3 , amorphous solar module shows a slightly better efficiency than mono-crystalline solar module. Table 2 shows the tabulated data for average module efficiency of each type of photovoltaic panels with average power output for 4 days period using single axis time/date solar tracker.

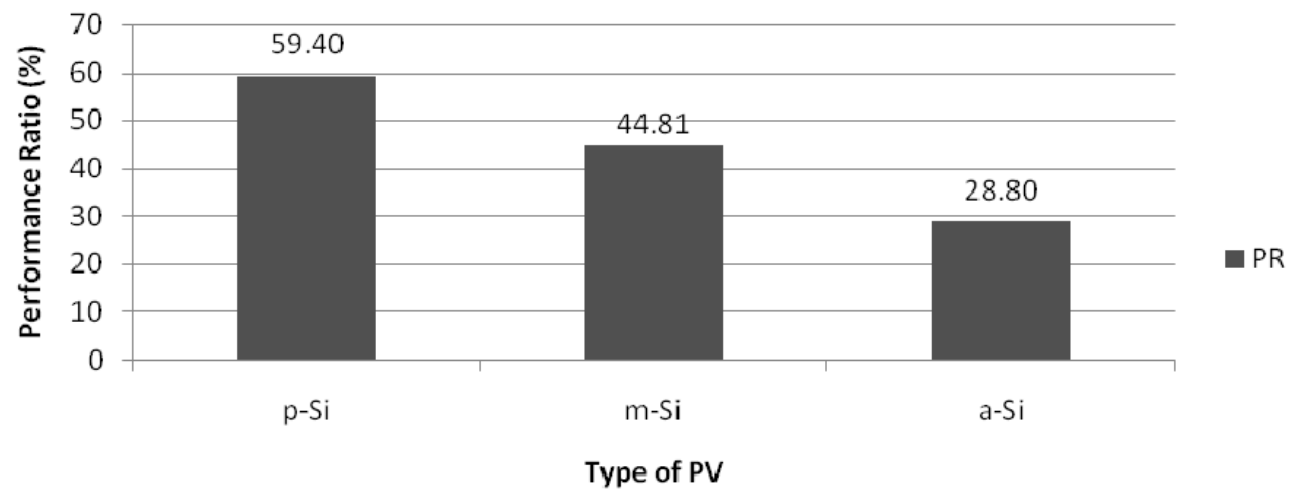

Figure 7. Performance ratio of each type of photovoltaic panel using single-axis time/date solar tracker

The performance ratio is one of the most important variables for evaluating the efficiency of a PV. The performance ratio is the ratio of the actual and theoretically possible energy outputs. It is largely independent of the location of a PV plant and the incident solar irradiation on the PV. Figure 7 shows the Performance Ratio of each type of photovoltaic panels in this experiment by using single-axis time/date solar tracker. From the graph, it can be seen that, the Performance Ratio for poly-crystalline solar module is $59.4 \%$ which is $14.59 \%$ higher compare to mono-crystalline (44.81\%). While Performance Ratio for amorphous solar module is the lowest, this is at $28.8 \%$ and this shows that poly-crystalline solar module performed better compare to mono-crystalline and amorphous. From this experiment, it can be conclude that poly-crystalline solar module are most suitable type of photovoltaic module to be used under Malaysian climate condition when applying single-axis time/date solar tracker.

The findings from this study are summarized as follow:

i. There are differences in performance between each type of photovoltaic module applying single-axis time/date solar tracker. It was observed during full-scale measurement study that the energy yield from each type of photovoltaic module showed is different although each module receives the same climate condition.

ii. Full-scale field measurement studies also found that all the module temperature are higher than ambient temperature for most of the time. This condition occurs due to the heat which is converted from the sun insolation when the photovoltaic process takes place.

iii. The module efficiency values quote by the manufacturer that have been tested under Standard Test Condition (STC) are not matched with the module efficiency measured on site under real climate condition either with dynamic system installation or static system installation.

iv. Poly-crystalline: show higher power output efficiency compare to mono-crystalline and amorphous in high level of average solar radiation per. While in low average solar radiation per day the power output for poly-crystalline are at low level compared to another photovoltaic module. This shows that, the 
performance of poly-crystalline are depending on the level solar radiation. The module temperatures for poly-crystalline is lower than mono-crystalline module, but slightly higher than amorphous module.

v. Mono-crystalline: power output efficiency for mono-crystalline was better in high average solar radiation per day. The power output of mono-crystalline drop as the module temperature reaches a high value. Comparing the module temperature between poly-crystalline, mono, crystalline and amorphous, mono-crystalline photovoltaic module produce more heat than the other modules

vi. Amorphous: in low intensity of solar radiation, amorphous photovoltaic module produces more power out then poly-crystalline and mono-crystalline photovoltaic modules. However in high intensity of solar radiation, the energy output for amorphous are low compared to poly-crystalline and mono-crystalline. Comparative observation of module temperature between each type of photovoltaic module, found that amorphous module has a cooler module temperature than poly-crystalline and mono-crystalline.

\section{Conclusion}

Developing a clean and renewable energy helps Malaysia safeguard its depleting energy resources. With the introduction of photovoltaic system and Malaysian climate condition which is almost predictable with the availability of 6 hours of direct sunlight per day with average solar radiation between $800 \mathrm{~W} / \mathrm{m}^{2}$ to $1000 \mathrm{~W} / \mathrm{m}^{2}$, provide a suitable condition to consider solar power as a promising renewable energy for Malaysia. Poly-crystalline, mono-crystalline and amorphous are types of PV panels most commonly use in Malaysia with different characteristic and efficiency. In this research, a solar tracker device (single-axis time/date) are being used to maximize the usage of sunlight in morning and afternoon performance to create more efficient solar energy by oriented the PV panels towards the sun's rays which incident on them from the normal direction. Poly-crystalline solar cell performed better in high level of solar radiation per day compared to amorphous and mono-crystalline. Meanwhile, during low intensity of solar radiation, amorphous solar cells efficiency is higher than the other two types of PV panel. The performance ratio for each type of PV modules show that poly-crystalline solar module are most suitable type of photovoltaic module to be used under Malaysian climate condition when applying single-axis time/date solar tracker

In built environment, by replacing the conventional type of solar installation with solar tracking installation, it's not only increase the performance of the PV panels installed but also, it can be integrate to the overall building design as part of Building Integrated Photovoltaic (BiPV) to perform specific function to the building envelope (e.g., provide shades on top of parking lot, minimize direct heat from sun at roof top, minimize direct sunlight for natural lighting). Besides that, the quantity of PV panels installed at the building can be reduced by using the solar tracking installation compare to the conventional type of installation (fixed installation). Hence these will influence the cost of the overall construction of the building. The combination of new green technology and well-design building will provides opportunities for sustainable building that not only energy efficient but also create a better environment.

\section{References}

A. J. Carr, \& T. L. Pryor. (2004). A comparison of the performance of different PV module types in temperate climates. Solar Energy, 76, 285-294. http://dx.doi.10.1016/j.solener.2003.07.02

Abdallah, S., \& Badran, O. O. (2008). Sun tracking system for productivity enhancement of solar still. Desalination, 220, 669-676. http://dx.doi.10.1016/j.desal.0000.00.00

Abdallah, S., \& Nijmeh, S. (2004). Two axes sun tracking system with PLC control. Energy Conversion and Management, 45, 1931-1939. http://dx.doi.10.1016/j.enconman.2003.10.007

Agee, J. T., Obok-Opok, A., \& Lazzer, M. D. (2007). Solar tracker technologies: market trends and field application. $\quad$ Advanced $\quad$ Research, $\quad 18-19, \quad 339-344$. http://dx.doi.10.4028/www.scientific.net/AMR.18-19.339

Akhmad, K., Kitamura, A., Yamamoto, F., Okamoto, H., Takakura, H., \& Hamakawa, Y. (1997). Outdoor performance of a-Si and p-Si modules. Solar Energy Materials and Solar Cells, 46, 209-218. http://dx.doi.10.1016/S0927-0248(97)00003-2

Anand, M. Sharan. (2009). Efficiency enhancement of stationary solar energy based power conversion system in Canada. Applied Energy, 86(9), 1405-1409. http://dx.doi.10.1016/j.apenergy.2008.11.032

Appleyard, D. (2009). Solar Tracker: Facing the Sun. London, UK: Renewable energy World Magazine. Vol. 12(13). Retrieved from http://www.renewableenergyworld.com/rea/news/article/2009/06/solar-trackers-fac ing-the-sun 
Deo Prasad, \& Mark Snow. (2005). Designing with Solar Power: A Source Book for Building Integrated Photovoltaic (BiPV). London: Earthscan, pp. 23.

Francisco Duarte, Pedro Dinis Gaspar, \& Luís Carrilho Gonçalves. (2010). Two axis solar tracker based on solar maps, controlled by a low-power Microcontroller", International Conference on Renewable Energies and Power Quality (ICREPQ’10) Granada (Spain), 23rd to 25th March, 2010.

Kamaruddin, R., B. J. Bailey, \& J. I. Montero. (2002). A naturally ventilation Greenhouse for temperate vegetable production in the tropics. Acta Horticulture, pp.578.

Mieke, W. (1998). Hot climate performance comparison between poly-crystalline and amorphous silicon cells connected to a utility mini-grid. In: Proceedings of Solar 98, 36th Annual Conference of the Australian and New Zealand Solar Energy Society, Christchurch, New Zealand, pp. 464-470.

Nowshad Amin, Chin Wen Lung, Kamaruzzaman Sopian. (2009). A practical field study of various solar cells on their performance in Malaysia. Renewable Energy, 34, 1939-1946. http://dx.doi.10.1016/j.renene.2008.12.005

Thomas Markvart. (1994). Solar Electricity. West Sussex: John Wiley \& Sons. P.1 